\title{
EFFECT OF PHYTASE SUPPLEMENTED MORINGA BY-PRODUCTS BASED DIETS ON The PERFORMANCE OF OREOCHROMIS NILOTICUS FINGERLINGS
}

\author{
M. M. Shahzad ${ }^{*}$, T. Rafique ${ }^{1}$, S. M. Hussain², Z. Hussain ${ }^{1}$, M. Y. Zahoor ${ }^{3}$, M. Hussain ${ }^{4}$, R. A. Rehman ${ }^{5}$, N. Ahmad ${ }^{2}$, I. \\ Liaquat $^{1}$ and S. Bashir ${ }^{1}$ \\ ${ }^{1}$ Department of Zoology, Division of Science and Technology, University of Education, Lahore, Pakistan. \\ ${ }^{2}$ Department of Zoology, Government College University Faisalabad, Pakistan. \\ ${ }^{3}$ Institute of Biochemistry and Biotechnology, University of Veterinary and Animal Sciences, Lahore, Pakistan. \\ ${ }^{4}$ Department of Zoology, University of Okara, Okara, Pakistan. \\ ${ }^{5}$ Department of Forensic Sciences, University of Health Sciences Lahore, Pakistan \\ Corresponding author's e-mail: drmudassarshahzad@gmail.com
}

\begin{abstract}
Increasing human population and lower food availability motivated the researchers to search out the alternative and low cost feed sources for fish that is the basic protein source in human diet. For this purpose, study was performed to develop an eco-friendly and low-cost feed for 'Nile tilapia' fingerlings using Moringa derived products supplemented with phytase (PHY) enzyme. Moringa oleifera seed meal and leaf meal were used as the major components to make seven iso-nitrogenous and iso-caloric test diets (TD). These Moringa based test diets were developed by using different PHY levels (0 control, 500, 650, 800, 950, 1100 and 1250 FTU per kg). Seven groups (in three replicates) of tilapia fingerlings were fed at the rate of $4 \%$ of their live weight two times a day. After 70 days feeding trials, blood samples from each replicate were collected for the analysis of hemato-immunological parameters. Then these fish were sacrificed and dried for carcass analysis. After the application of one-way ANOVA, maximum retention of protein (18.26\%) and fat (8.92) were found at 950 FTU per $\mathrm{kg}$ in comparison to other test diets. Study of hematological indices revealed that the maximal values of RBCs $\left(2.92 \times 10^{6} \mathrm{~mm}^{-3}\right)$, PLT (64) and $\mathrm{Hb}(8.19 \mathrm{~g} / 100 \mathrm{ml})$ were recorded at 950 FTU per kg level. Similarly, highest MCH, PCV, MCV and Ht. were also observed at 950 FTU per kg level. For the study of expression of growth genes, gel electrophoresis method was performed. It was concluded that PHY added diet at 950 FTU per kg showed maximum improvement in hemato-immunological parameters and body composition of tilapia with no side effects on fish health and non-differentiable results regarding growth gene expression.
\end{abstract}

Keywords: Carcass, hematology, Nile tilapia, Phytase, Moringa oleifera.

https://doi.org/10.36899/JAPS.2021.1.0216

Published online August 26, 2020

\section{INTRODUCTION}

In food-producing industries, one of the developing and advance industry is the aquaculture (Yildirim et al. 2014). Many problems faced by aquaculture now a days and feed is one of them that limits profitability. Feed that provided the fish should be stable, environment-friendly, normally available and cost effective (Shahzad et al. 2016;2019). Fishmeal (FM) in feed costs about $40-60 \%$ of total production charges in farms (Foidl et al. 2001). Plant meal-based diets proved to be suitable and economically profitable for aquaculture by many researchers (Mahmoud et al. 2016). Various feed ingredients from plants are used as the alternate source of FM on trial basis. Using plant derived products as a source of food for aquaculture may have certain major problems. Moringa seeds are enriched with phytate (an anti-nutritional agent) and it cannot be catabolized by fish, consequently discharged into surrounding water and cause water contamination (NRC 1993).
In Pakistan, Moringa oleifera is commonly called 'sohanjana' or 'sanjana' and located in Southern Punjab, is an excellent protein-rich plant and proved to be a cost-effective source for fish feed (Chiseva 2006). $M$. oleifera seeds are excellent source of protein (33 to 38\%). Certain important amino acids e.g., methionine, cysteine and glycine and some essential minerals are also present in seeds (Hassan et al. 2018; Liang et al. 2019). Leaves of Moringa have high quantity of protein varying from 23\% (Hassan et al. 2018) 32\% (Soliva et al. 2005) and higher content of minerals and nutrients (Liang et al. 2019). Minerals that Moringa seeds carry include $\mathrm{Na}, \mathrm{P}$, $\mathrm{Zn}, \mathrm{Mg}, \mathrm{K}, \mathrm{Fe}$ and $\mathrm{Ca}$ etc. (Anjorin et al. 2010).

There are three common problems with Moringa feed that are caused by the presence of phytic acid in Moringa based diets and deficiency of PHY in fish digestive system; undigested phosphorous remains unabsorbed and excreted through faeces (Lei et al. 2013). The gene expression level of fatty acid synthase (FAS), the regulatory element binding protein of sterol and growth genes were negatively regulated by the excess 
phosphorus level in fish body (Ji et al. 2017). Adverse effects of phytate in the plant-based diet can be minimized by using PHY enzyme (Hussain et al. 2015; Shahzad et al. 2018). After the breakdown of phytic acid by PHY enzyme, bounded cationic minerals become free for the consumption of organism and also minimize the release of phosphorus in the environment through excretions (Vohra et al. 2006).

Plant ingredients in feed were also reported negatively in immune functions of fish due to the presence of phytic acid (Sitjà-Bobadilla et al. 2005; Kokou et al. 2012). Erythrocyte (RBC) count, leucocyte (WBC) count, $\mathrm{Hb}$ concentration and hematocrit provide important knowledge about development, health and stress responses of fish for ichthyologists (Hrubec et al. 2000). WBC count also proves helpful for the monitoring of immune responses (Blaxhall 1972; Soivio and Oikari 1976). Monocytes, neutrophil, eosinophil and lymphocytes are the basic parameters for the demonstration of immunity of fish. Less research work was reported in past on hematology and immunity of Nile tilapia. Therefore, this research work was conducted to produce higher quality meat of fish at lowest cost by using PHY added Moringa derived products and also to improve hemato-immunological indices of tilapia.

\section{MATERIALS AND METHODS}

This work was performed from November 2018 to May 2019to study the body composition, hematology, immunity and growth gene expression of Nile tilapia fed on Moringa derived product based diet. Research work was performed in the Fish Nutrition Lab, DSNT, University of Education, Lahore, Pakistan $\left(31.4537^{\circ} \mathrm{N}\right.$, $\left.74.2990^{\circ} \mathrm{E}\right)$.

Fish and experimental treatments: Tilapia were purchased from Manawan Fish Hatchery, Lahore and stocked in V-shaped fish tanks for two-week acclimatization period. Saline solution was used to treat fish for 5-7 minutes to kill disease causing microorganisms (Rowland and Ingram 1991). Different parameters like $\mathrm{pH}$, temperature and dissolved oxygen were monitored for the quality of water on daily basis. For respiration, air is supplied by capillary system using air pump.

Experimental design: For the preparation of test diets, derived products of Moringa were used as feed ingredients. Moringa derived products based diets were developed by using various levels of supplementation of PHY (0, 500, 650, 800, 950, 1100 and 1250 FTU per kg); one control (without PHY) and six test diets. To check the effect of these test diets, eighteen fingerlings were kept in each triplicate tank (total 21 tanks). Fingerlings (Average weight $6.86 \mathrm{~g} \mathrm{fish}^{-1}$ Average length $7 \mathrm{~cm}$ ) were fed two times in a day with $4 \%$ of feeding rate of their live weight. In each triplicate, fish were fed on control and test diets of specific graded levels of PHY. Total duration of the experimental trial was conducted following a completely randomized design (CRD) for a period of 70 days. C. carpio fingerlings fed with test diets were compared with control as well as between test groups to assess body composition, hematology and immunological parameters.

Pellets Formation and feeding: Collected Moringa leaves and seeds were crushed and ground as fine powder after their processing as described by Shahzad et al. (2019). Proximate chemical composition of all feed ingredients was done (AOAC 1995) before pellet formation (Table 1). All feed items in specific proportion were mixed for approximately 5 minutes. The fish oil was poured into the mixer very slowly. Distilled water (15$20 \%$ ) was added in the feed; consequently, textured dough was produced. Hand pelleting machine was used for further processing of dough to make feeding pellets (Lovell, 1989). There were seven diets; one control and six test diets. Solutions with different PHY concentrations $(500,650,800,950,1100$ and 1250 FTU per $\mathrm{kg}$ ) were sprayed on test diets having weight of one kilogram each (Robinson et al. 2002). To maintain normal moisture contents of feed, equal volume of distilled water was sprayed on control diet. Freshly prepared diets were dried normally in shady and cool place and stored at $4{ }^{\circ} \mathrm{C}$ in air tight jars until use. Tanks were washed after one hour of feeding with fresh water thoroughly to remove remaining particles of feed to decrease the contamination of water and tanks were filled with fresh water.

Analysis of carcass: Three fish were brought out from each tank and sacrificed after feeding trial. The fish carcass samples were dried at room temperature (for 2 days till the samples got dried) and crushed into fine powder separately using pestle and mortar (AOAC 1995). For the removal of moisture, oven-drying method was used for about 12 hours at $105^{\circ} \mathrm{C}$. For the analysis of crude fat, petroleum ether extraction (EE) method was used with Soxhlet apparatus. Crude protein (CP) was determined with the use of Micro Kjeldahl's apparatus. After digestion with $1.25 \% \mathrm{NaOH}$ and $1.25 \% \mathrm{H}_{2} \mathrm{SO}_{4}$, crude fiber (CF) contents were checked by ignition of lipid-free dried residue forming ash in electric furnace (Naberthern B170) for about 10 hours at $650^{\circ} \mathrm{C}$ to constant weight. Total carbohydrate contents were calculated using following formula (FAO 2003):

Total carbohydrates $(\%)=100$ - (Moisture $\%+$ CP $\%+$ $\mathrm{CF} \%+\mathrm{EE} \%+$ Ash \%)

Analysis of hematological parameters: After feeding trial, blood samples (randomly selected fingerling; one from each replicate) from each replicate were collected for analysis. The samples were collected with 
anticoagulant i.e. $10 \%$ ethylene diamine tetraacetate (EDTA). These collected blood samples were taken to Hematological Lab for analysis. Hematocrit was analyzed by the help of capillary tube method using Microhematocrit technique (Brown 1988). RBC's and WBC's were counted with the help of haemo-cytometer using Neubauer Counting Chamber method (Blaxhall and Daisley 1973). Concentration of hemoglobin ( $\mathrm{Hb})$ in different samples was checked as explained by Wedemeyer and Yastuke (1977). To calculate $\mathrm{MCH}$ (mean corpuscular hemoglobin); MCHC (mean corpuscular hemoglobin concentration); and MCV (mean cell volume), the following mathematical relations were used:

$\mathrm{MCHC}=100(\mathrm{Hb} /$ Packed Cell Volume $)$

$\mathrm{MCH}=10(\mathrm{Hb} / \mathrm{RBC})$

$\mathrm{MCV}=10(\mathrm{PCV} / \mathrm{RBC})$

Blood samples for the analysis of immunological indices were collected without anticoagulant. For the analysis of immunological indices, these samples were stored in a freezer at $-20^{\circ} \mathrm{C}$. Smears of blood samples were prepared for the determination of lymphocytes, eosinophils, monocytes and neutrophils with Neubauer differential counting method. Centrifugation method was used for the separation of serum samples (Schalm 1986).

Collection of muscle sample for gel electrophoresis: In clean Eppendorf tubes, the muscle samples, from four Tilapia of each group, were collected separated and preserved at $-80^{\circ} \mathrm{C}$ till use at the end of experiment and FAS and LPL were analyzed (Norag et al. 2018).Gel electrophoresis was performed at one hundred and twenty volt for 30 minutes and results observed under UV iluminator. Bands of amplified cDNA of FAS and LPL genes were compared to differentiate the level of gene expression in Tilapia.

Statistical Analysis: The data obtained were statistically analyzed by One-Way ANOVA using Co-Stat computer software package to study the effect of different PHY treated diets on fish fingerlings. The variations among different parameters were compared by using Tukey's Honesty Significant Difference Test. These differences were considered significant at $\mathrm{P}<0.05$ (Snedecor and Cochran 1991).

\section{RESULTS AND DISCUSSION}

Composition of fish body fed Moringa based diets with the addition of PHY is given in Table 2. PHY added diets showed significant improvements in fish body composition by the maximum absorption of nutrients in comparison to control diet. Maximum contents of crude protein $(18.26 \%)$, crude fat $(8.92 \%)$ and gross energy $(2.21 \mathrm{kcal} / \mathrm{g})$ were observed at $950 \mathrm{FTU}$ per kg PHY added Moringa derived based diets. These values were different significantly from the values found in fingerlings fed with control and other test diets. Fish with control diet gave least contents of crude protein $(12.86 \%)$, crude fat $(6.45 \%)$ and gross energy $(1.06$ $\mathrm{kcal} / \mathrm{g}$ ). Moringa derived products based diets with the addition of PHY improved the retention of protein according to many aqua-culturists (Lanari et al. 1998; Debnath et al. 2005; Khajepour et al. 2012). Closely similar to our results, maximum retention of protein, fat and gross energy were recorded at 900 FTU per $\mathrm{kg}$ addition of PHY in Catla catla fed Moringa by-products meal based diets (Shahzad et al. 2016,2018). Cheng et al. (2015) recorded that plant based diets at $1000 \mathrm{FTU}$ per $\mathrm{kg}$ addition of PHY show maximum protein and fat in Pelteobagrus fulvidraco (yellow catfish). However, Olusola and Nwanna (2014) strongly disagreed with these findings. They found maximum retention of protein in Nile tilapia was recorded at very high addition of PHY at (8000 FTU per kg) fed on soy-bean plant based diets. A little disagreement was observed by Yoo and Bai (2014). Highest fat contents in carcass of Olive Flounder (Paralichthy solivaceus) were found at $1000 \mathrm{FTU}$ per $\mathrm{kg}$ addition of PHY in soybean based diets. Hung et al. (2015) noted that dietary inclusion of PHY enzyme at 1500 FTU per $\mathrm{kg}$ in soybean plant based diets significantly improves the retention of crude protein in Pangasianodon hypophthalmus (Tra catfish). In the light of above-mentioned results, we can argue that the possible explanations for dissimilarities in values of results may be the quantity, quality (Baruah et al., 2007; Dersjant-Li et al., 2015) and dissimilar sources of PHY, feed components, methods of diet formulation or changed fish species (Liu et al., 2013).

Highest contents of ash (6.03\%) and moisture $(72.51 \%)$ were found in fish fed on diet without addition of PHY and were different significantly from other replicates with PHY addition. While increasing the level of PHY caused gradual decrease in ash and moisture contents till 950 FTU per $\mathrm{kg}(5.12 \%$ and $64.53 \%$ respectively) and then gradual increase was occurred from $1100 \mathrm{FTU}$ per $\mathrm{kg}$ to $1250 \mathrm{FTU}$ per $\mathrm{kg}$. It was observed that improvement of protein and lipids in fish body starts from 500 FTU per kg level and reached to its highest when tilapia were fed at 950 FTU per kg PHY added Moringa derived based diet. However, more increase in PHY from 1100 to 1250 FTU per kg resulted a decrement in retention of nutrients in fish body. Results of carcass parameters showed that 950 FTU per kg PHY in Moringa based diets was very suitable for the maximum retention of nutrients by fish. Similarly, Hossain et al. (2007) observed that Red sea bream fed with plant derived products based diet shows decreasing trends in crude ash and moisture values and improvement in crude protein values. Sardar et al. (2007) also agreed with the current findings and noted higher values of moisture at PHY level (0 FTU per kg) in Cyprinus 
carpio. Shahzad et al. (2016;2018;2020) strongly agreed with the current results of the study and observed least contents of body ash, crude fiber and moisture in Catla catla were found at $900 \mathrm{FTU}$ per $\mathrm{kg}$ addition of PHY in Moringa leaf meal based diets. Whereas, non-significant differences were observed by Cheng et al. (2015) in fish body carcass irrespective of PHY addition. Nwanna et al. (2008) in contrast found that, leucaena leaf meal and Brazil nut based diets irrespective of PHY addition showed non-significant differences in lipid contents of Colossoma macropomum, Amazon tambaqui fish. The contradictions and variations in results are considered to occur because of the type and source of PHY enzyme used, numerous nutritional factors, along with the source and quantity of phytic acid (Selle et al. 2000) and protein sources in fish diets (Sugiura et al. 2001).

Based on the present findings, improvement in hematological parameters such as RBC $\left(2.9210^{6} \mathrm{~mm}^{-3}\right)$, PLT (63.77), hemoglobin ( $8.19 \mathrm{~g} / 100 \mathrm{ml})$, PCV (26.39) and Ht. (32.91) was observed in fish fed on test diet IV (950 FTU per kg). Second highest values (RBC $2.7010^{6}$ $\mathrm{mm}^{-3}$, PLT 62.77, PCV 25.75 and Ht. 31.60) were noted in fish fed on 800 FTU per kg level based diet. Similarly Ehsani and Torki (2010) also found that the addition of PHY stimulates the immune system of fish producing high number of macrophages. With agreement of current study, Shahzad et al. (2019;2020) also noted closely similar results. They observed high contents of RBCs and $\mathrm{Hb}$ in Catla catla were observed in diet having $900 \mathrm{FTU}$ per kg PHY level. Whereas, in contradiction to our results, highest counts of WBCs and RBCs were observed at 500 FTU per $\mathrm{kg}$ in C. carpio fed diet consisting of soya-bean plant added with PHY and dicalcium phosphate (Sardar et al. 2007).On the other hand, lowest values of the said parameters were found in the fingerlings that were fed with control diet. Whereas, highest value of WBCs $\left(6.9110^{3} \mathrm{~mm}^{-3}\right)$ was observed at control diet and started to decrease from test diet 2 . Lowest WBCs $\left(6.4810^{3} \mathrm{~mm}^{-3}\right)$ were noted at diet IV. The Overall values of WBCs were not significantly different from the fingerlings fed on other test diets. Maximum number of Lymphocytes (25.97\%) and Monocytes $(2.94 \%)$ were found in the fingerlings that were fed at test diet 4 supplemented with 950 FTU per kg of phytase as compared to other test diets. Whereas higher Eosinophils $(1.63 \%)$ were found in the fingerlings fed on test diet 6 and Neutrophils (79.60\%) at control diet. Low count of Eosinophile (1.16) and Neutrophile (69.92) was observed in fish fed diet IV (950 FTU per kg). Different immune responses were observed in fish fed with different diets having different PHY levels but fish fed with diet IV produced slightly better results compared to other test diets. WBCs count played very important role in innate immunity of fish and their count can be used as tool to check the health status of fish. WBC count will increase in conditions of stress i.e. dietary imbalance, certain infection etc. (Roberts 1978). Whereas, some researchers found positive results by using real time PCR techniques to study the expression of genes (lipoprotein lipase i.e. LPL and fatty acid synthase i.e. FAS) of fish fed PHY added diets. They concluded that PHY played an important role in positive regulation of genes expression in fish body (Norag et al. 2018). A little research work has been performed to study the impact of PHY on growth genes such as LPL and FAS of fish. In another experiment Norag et al. (2018) studied the influence of low phosphorus diet with or without PHY addition on the expression of LPL and FAS genes of tilapia. They concluded that normal phosphorus was helpful in positive regulation of (LPL) mRNA expression and negative regulation of (FAS) mRNA in the liver of tilapia. They use PCR technique to check the impact of PHY on gene expression. Whereas, current outcomes indicate that comparative gene expression was not differentiable. The optimum range of PHY is 250 to 1500 FTU per $\mathrm{kg}$ in plant diets as described by many aqua-culturists in different fishes (Cao et al. 2007; Shahzad et al. 2016).These contradictory values of results as abovementioned might be due to the source of PHY, feed components, methods of diet formulation or changed fish species (Cao et al., 2007).

Table 1. Physical and chemical Constituents composition (\%) of diet (dry matter).

\begin{tabular}{lcccccccc}
\hline \multicolumn{1}{c}{ Physical composition (\%) of test diet } & \multicolumn{6}{c}{ Chemical composition (\%) of feed constituents } \\
\hline \multicolumn{1}{c}{ Constituents } & TD composition & $\begin{array}{c}\text { Dry } \\
\text { matter } \\
\text { (\%) }\end{array}$ & $\begin{array}{c}\text { Crude } \\
\text { Protein } \\
\text { (\%) }\end{array}$ & $\begin{array}{c}\text { Crude } \\
\text { Fat } \\
\mathbf{( \% )}\end{array}$ & $\begin{array}{c}\text { Crude } \\
\text { Fiber } \\
\text { (\%) }\end{array}$ & $\begin{array}{c}\text { Ash } \\
\text { (\%) }\end{array}$ & $\begin{array}{c}\text { Gross } \\
\text { Energy } \\
\text { (kcal per g) }\end{array}$ & Carbohydrates \\
\hline MOSM+MOLM & 36 & 91.24 & 33.31 & 3.91 & 13.56 & 10.07 & 4.02 & 39.15 \\
Fishmeal & 17 & 92.39 & 49.31 & 6.99 & 1.29 & 24.66 & 2.23 & 17.75 \\
Corn Gluten (60\%) & 13 & 91.78 & 58.97 & 4.96 & 1.23 & 1.41 & 4.21 & 33.43 \\
Wheat flour & 16 & 93.09 & 9.43 & 2.41 & 2.88 & 2.06 & 3.09 & 83.22 \\
Rice polish & 7.5 & 92.2 & 13.02 & 12.76 & 13.06 & 11.17 & 3.03 & 49.99 \\
Fish oil & 6.5 & & & & & & & \\
Mineral Premix & 1 & & & & & & & \\
Chromic oxide & 1 & & & & & & & \\
\hline
\end{tabular}




\begin{tabular}{|c|c|c|c|c|c|c|}
\hline $\begin{array}{l}\text { Vitamin Premix } \\
\text { Ascorbic acid } \\
\text { Total }\end{array}$ & & & & & & \\
\hline \multicolumn{7}{|c|}{ Nutrients in test and control diet supplemented with PHY fed $O$. niloticus } \\
\hline TD-I (Control diet) & TD -II & TD -III & TD -IV & TD $-V$ & TD -VI & TD -VII \\
\hline PHY level & 500 & 650 & 800 & 950 & 1100 & 1250 \\
\hline CP in diet & 31.56 & 31.58 & 31.59 & 31.56 & 31.59 & 31.56 \\
\hline EE in diet & 6.19 & 6.20 & 6.18 & 6.18 & 6.17 & 6.20 \\
\hline GE in diet & 3.53 & 3.50 & 3.51 & 3.50 & 3.51 & 3.53 \\
\hline 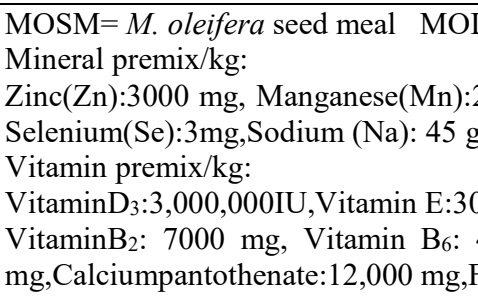 & $\begin{array}{l}\text { M. oleif } \\
\text { mg, Ca } \\
\text { dine (I): } \\
\text { IU, Vita } \\
0 \mathrm{mg}, \mathrm{V} \\
\text { cacid: } 150\end{array}$ & $\begin{array}{l}\text { f meal } \\
\text { Ca ): } 155 \\
\text { Phosphor } \\
15,000,0 \\
\text { B }_{12}: 40\end{array}$ & $\begin{array}{l}\text { Copper: } \\
\text { : } 135 \mathrm{~g}, \mathrm{\Lambda} \\
\text { VitaminB } \\
\text { taminC: } 15\end{array}$ & $\begin{array}{l}\text { g, Iron }(\mathrm{F} \\
\text { ium }(\mathrm{Mg}) \\
\text { mg, } \\
\text { g, Vitamin }\end{array}$ & $\begin{array}{l}00 \mathrm{mg}, \mathrm{Co} \\
\text { 000mg,Nic }\end{array}$ & $\begin{array}{l}\text { Co): } 40 \mathrm{mg}, \\
\text { cacid: } 60,000\end{array}$ \\
\hline
\end{tabular}

Table 2. Proximate analysis of tilapia carcass fed PHY added Moringa derived products meal based diets.

\begin{tabular}{|c|c|c|c|c|c|c|c|}
\hline Diets & $\begin{array}{c}\text { PHY level } \\
\text { (FTU per kg) }\end{array}$ & $\begin{array}{c}\text { Crude } \\
\text { Protein } \\
\end{array}$ & Crude Fat & $\begin{array}{c}\text { Gross } \\
\text { energy }\end{array}$ & Ash & Crude fiber & Moisture \\
\hline Control diet & 0 & $12.86^{\mathrm{e}}$ & $6.45^{d}$ & $1.06^{\mathrm{c}}$ & $6.03^{a}$ & $1.08^{\mathrm{a}}$ & $72.51^{\mathrm{a}}$ \\
\hline TD 1 & 500 & $13.98^{\mathrm{d}}$ & $6.99^{\mathrm{cd}}$ & $1.40^{\mathrm{bc}}$ & $5.89^{\mathrm{ab}}$ & $1.15^{\mathrm{a}}$ & $70.59^{b}$ \\
\hline TD 2 & 650 & $15.20^{\mathrm{c}}$ & $7.67^{\mathrm{bc}}$ & $1.64^{\mathrm{ab}}$ & $5.72^{\mathrm{abc}}$ & $1.09^{\mathrm{a}}$ & $68.67^{\mathrm{c}}$ \\
\hline TD 3 & 800 & $16.72^{\mathrm{b}}$ & $8.18^{\mathrm{ab}}$ & $1.86^{\mathrm{ab}}$ & $5.52^{\mathrm{bcd}}$ & $1.14^{\mathrm{a}}$ & $66.58^{\mathrm{d}}$ \\
\hline TD 4 & 950 & $18.26^{\mathrm{a}}$ & $8.92^{\mathrm{a}}$ & $2.21^{\mathrm{a}}$ & $5.12^{\mathrm{d}}$ & $0.97^{\mathrm{a}}$ & $64.53^{\mathrm{e}}$ \\
\hline TD 5 & 1100 & $17.33^{\mathrm{b}}$ & $8.12^{\mathrm{ab}}$ & $1.86^{\mathrm{ab}}$ & $5.39^{\mathrm{cd}}$ & $1.01^{\mathrm{a}}$ & $66.29^{d}$ \\
\hline TD 6 & 1250 & $13.94^{\mathrm{d}}$ & $7.13^{\mathrm{cd}}$ & $1.56^{\mathrm{bc}}$ & $5.69^{\mathrm{abc}}$ & $1.14^{\mathrm{a}}$ & $70.54^{\mathrm{b}}$ \\
\hline \multicolumn{2}{|c|}{ SE } & 0.41962 & 0.18458 & 0.08489 & 0.07054 & 0.02138 & 0.59933 \\
\hline
\end{tabular}

${ }^{\mathrm{a}-\mathrm{d}}$ Means within column having dissimilar superscripts are quietly different at $p<0.05$. Data are means of three replicates

( $\mathrm{SE}=$ Standard Error)

Table 3. Hematological indices of Nile Tilapia fed PHY added Moringa based diets.

\begin{tabular}{|c|c|c|c|c|c|c|c|c|}
\hline Diets & Control diet & TD 1 & TD 2 & TD 3 & TD 4 & TD 5 & TD 6 & \\
\hline PHY Levels (FTU/kg) & 0 & 500 & 650 & 800 & 950 & 1100 & 1250 & SE \\
\hline $\operatorname{RBC}\left(10^{6} \mathrm{~mm}^{-3}\right)$ & $1.12^{\mathrm{e}}$ & $1.87^{\mathrm{d}}$ & $2.11^{\mathrm{cd}}$ & $2.71^{\mathrm{ab}}$ & $2.92^{\mathrm{a}}$ & $2.46^{\mathrm{bc}}$ & $1.96^{\mathrm{d}}$ & 0.12730 \\
\hline WBC $\left(10^{3} \mathrm{~mm}^{-3}\right)$ & $6.91^{\mathrm{a}}$ & $6.81^{\mathrm{ab}}$ & $6.59^{\mathrm{ab}}$ & $6.66^{\mathrm{ab}}$ & $6.48^{\mathrm{b}}$ & $6.72^{\mathrm{ab}}$ & $6.78^{\mathrm{ab}}$ & 0.04060 \\
\hline PLT & $55.49^{\mathrm{e}}$ & $58.79^{d}$ & $61.51^{\mathrm{bc}}$ & $62.61^{\mathrm{ab}}$ & $63.77^{\mathrm{a}}$ & $60.54^{\mathrm{cd}}$ & $54.68^{\mathrm{e}}$ & 0.73089 \\
\hline $\mathrm{Hb}(\mathrm{g} / 100 \mathrm{ml})$ & $4.97^{\mathrm{f}}$ & $5.69^{\mathrm{ef}}$ & $6.68^{\mathrm{cd}}$ & $7.24^{\mathrm{bc}}$ & $8.19^{\mathrm{a}}$ & $7.57^{\mathrm{ab}}$ & $5.87^{\mathrm{de}}$ & 0.24429 \\
\hline $\operatorname{PCV}(\%)$ & $21.47^{\mathrm{c}}$ & $23.80^{\mathrm{b}}$ & $24.09^{\mathrm{b}}$ & $25.75^{\mathrm{a}}$ & $26.39^{\mathrm{a}}$ & $23.43^{\mathrm{b}}$ & $21.62^{\mathrm{c}}$ & 0.40004 \\
\hline МCHC (\%) & $27.90^{\mathrm{e}}$ & $30.46^{\mathrm{d}}$ & $32.48^{\mathrm{bc}}$ & $35.34^{\mathrm{a}}$ & $34.22^{\mathrm{ab}}$ & $33.32^{\mathrm{bc}}$ & $31.55^{\mathrm{cd}}$ & 0.52848 \\
\hline MCH (pg) & $31.43^{\mathrm{f}}$ & $38.49^{\mathrm{e}}$ & $42.41^{\mathrm{d}}$ & $48.92^{\mathrm{b}}$ & $49.26^{\mathrm{b}}$ & $54.62^{\mathrm{a}}$ & $44.71^{\mathrm{c}}$ & 1.59813 \\
\hline $\operatorname{MCV}$ (fl) & $101.32^{\mathrm{f}}$ & $88.23^{\mathrm{g}}$ & $129.44^{\mathrm{e}}$ & $197.48^{\mathrm{a}}$ & $165.52^{\mathrm{b}}$ & $160.80^{c}$ & $148.37^{\mathrm{d}}$ & 7.89728 \\
\hline Hematocrit (Ht) \% & $22.76^{\mathrm{d}}$ & $28.28^{\mathrm{b}}$ & $29.90^{\mathrm{b}}$ & $31.60^{\mathrm{a}}$ & $32.91^{\mathrm{a}}$ & $29.39^{\mathrm{b}}$ & $24.92 \mathrm{~s}^{\mathrm{c}}$ & 0.75214 \\
\hline
\end{tabular}

${ }^{\mathrm{a}-\mathrm{d}}$ Means within rows having dissimilar superscripts are quietly different at $p<0.05$. Data are means of three replicates $(\mathrm{SE}=\mathrm{Standard}$ Error).

Table 4. Immunological parameters of Nile Tilapia fed PHY added Moringa based diets.

\begin{tabular}{|c|c|c|c|c|c|c|c|c|}
\hline Diets & Control diet & TD 1 & TD 2 & TD 3 & TD 4 & TD 5 & TD 6 & \\
\hline PHY Levels (FTU/kg) & 0 & 500 & 650 & 800 & 950 & 1100 & 1250 & SE \\
\hline Lymphocyte \% & $15.78^{d}$ & $18.47^{\mathrm{c}}$ & $19.83^{c}$ & $24.95^{\mathrm{a}}$ & $25.97^{\mathrm{a}}$ & $22.16^{\mathrm{b}}$ & $18.82^{\mathrm{c}}$ & 0.77237 \\
\hline Eosinophil \% & $1.48^{\mathrm{ab}}$ & $1.41^{\mathrm{ab}}$ & $1.35^{\mathrm{ab}}$ & $1.29^{\mathrm{ab}}$ & $1.16^{\mathrm{b}}$ & $1.24^{\mathrm{ab}}$ & $1.63^{\mathrm{a}}$ & 0.04201 \\
\hline Monocyte \% & $3.15^{\mathrm{a}}$ & $2.79^{\mathrm{ab}}$ & $2.34^{\mathrm{bc}}$ & $2.05^{\mathrm{cd}}$ & $2.94^{\mathrm{a}}$ & $1.75^{\mathrm{d}}$ & $1.77^{\mathrm{d}}$ & 0.12201 \\
\hline Neutrophil \% & $79.60^{\mathrm{a}}$ & $77.32^{\mathrm{b}}$ & $76.48^{\mathrm{bc}}$ & $71.72^{\mathrm{d}}$ & $69.92^{\mathrm{e}}$ & $74.84^{\mathrm{c}}$ & $77.77^{\mathrm{b}}$ & 0.72607 \\
\hline
\end{tabular}


Conclusion: It was revealed from the results that addition of PHY gave positive results regarding fish carcass composition and hemato-immunological parameters. Fish that were fed with PHY added Moringa derived products meal-based diets showed improvement in nutrient retention and hematological parameters in whole fish body as compared to fish fed on control diet ( 0 FTU per $\mathrm{kg}$ ). Results revealed that diet IV (950 FTU per $\mathrm{kg}$ ) is most suitable level that significantly enhanced the hemato-immunological indices and carcass of tilapia. But unfortunately, expression of genes was not differentiable by gel electrophoresis technique.

Acknowledgement: The authors are grateful to Higher Education Commission, Islamabad, Pakistan for financial support by funding project No. "SRGP 2047/2018" and University of Education, Lahore for facilitating this research work.

\section{REFERENCES}

Anjorin, T.S., P. Ikokoh, and S. Okolo (2010). Mineral composition of Moringa oleifera leaves, pods and seeds from two regions in Abuja, Nigeria. Int. J. Agric. Bio., 12: 431-434.

AOAC (1995). Official Methods of Analysis $15^{\text {th }}$ edition. Page number 1094.Washington, D.C. USA.

Baruah, K., N.P. Sahu, A.K. Pal, K.K. Jain, D. Debnath, and S.C. Mukherjee (2007). Dietary microbial phytase and citric acid synergistically enhances nutrient digestibility and growth performance of Labeo rohita (Hamilton) juveniles at suboptimal protein level. Aqua. Res., 38: 109-120.

Blaxhall, P.C. (1972). The haematological assessment of the health of freshwater fish. A review of selected literature. J. Fish. Bio.,4:593-604.

Blaxhall, P.C., and K.W. Daisley (1973). Routine haematological methods for use with fish blood. J. Fish. Bio.,6:771-781.

Brown, B. A. (1988). Routine hematology procedures. Hematology: Principle and Procedures. 7-122.

Cao, L., W. Wang, C. Yang, Y. Yang, J. Diana, A. Yakupitiyage, Z. Luo, and D. Li (2007). Application of microbial phytase in fish feed. J Enzyme Microb Technol. 40: 497-507.

Cheng, N., P. Chen, W. Lei, M. Feng, and C. Wang (2015). The sparing effect of phytase in plant protein based diets with decreasing addition of dietary $\mathrm{NaH}_{2} \mathrm{PO}_{4}$ for juvenile yellow catfish Pelteobagrusfulvidraco. Aquacul Res. 1-12.

Chiseva, S. (2006). The growth rates and feed conversion ratios of fry fed conventional fry diets and Moringa oleifera added diets. B.Sc. Dissertation, Bindura Univ (Science Education), Zimbabwe.
Debnath, D., N.P. Sahu, A.K. Pal, K.K. Jain, S. Yengkokpam, and S.C. Mukherjee (2005). Mineral status of Pangasius pangasius(Hamilton) fingerlings in relation to supplemental phytase: absorption, whole-body and bone mineral content. Aquacul Res. 36: 326-335.

Dersjant-Li, Y., A. Awati, H. Schulze, and G. Partridge (2015). Phytase in non-ruminant animal nutrition: a critical review on phytase activities in the gastrointestinal tract and influencing factors. J Sci Food and Agri, 95: 878-896.

Ehsani, M., and M. Torki (2010). Effects of dietary inclusion of guar meal added by $\beta$-mannanase on performance of laying hens, egg quality characteristics and diacritical counts of white blood cells. American J Anim Veterinary Sci. 5: 237-243.

FAO (Food and Agriculture Organization of the United Nations) (2003). Food Energy: Methods of Analysis and Conversion Factors: Report of a Technical Workshop, Rome, 3-6 December

Foidl, N., H.P.S. Makkar, and K. Becker (2001). The potential of Moringa oleifera for agricultural and industrial uses. The miracle tree: Multiple attributes of Moringa.45-76.

Hassan, S. K. U., A. Khalique, T. N. Pasha, and A. W. Sahota. (2018) Effect of dried Moringa oleifera leaves on growth performance and immune response of broilers. J Anim. and Plant Sciences 28(6): 1579-1583.

Hossain, M.A., A. Pandey, and S. Satoh (2007). "Effects of organic acids on growth and phosphorus utilization in red sea bream Pagrus major. Fish. Sci. 73: 1309-1317.

Hrubec, T.C., J.L. Cardinale, and S.A. Smit (2000). Haematology and plasma chemistry reference intervals for cultured tilapia (Oreochromis hybrid). Veterinary Clinic Pathol. 29:7-12.

Hung, L.T., N.T. Thanh, M.A. Pham, and C.L. Browdy (2015). A comparison of the effect of dietary fungal phytase and dicalcium phosphate addition on growth performances, feed and phosphorus utilization of tra catfish juveniles (Pangasianodonhypophthalmus). Aquacul Nutr. 21: 10-17.

Hussain, S.M., M. Afzal, A. Javid, A.I. Hussain, Q. Ali, I. Mustafa, S.A.S. Chatha, S.Z.H. Shah, M. Hussain, and M.I. Ullah (2015). Efficacy of phytase addition on growth performance and mineral digestibility of Labeo rohitafingerlings fed on cottonseed meal based diet. Pak J Zool. 47: 699-709.

Ji, K., H., Liang, H., Mi, A., Mokrani, J., Xie, B, Liu, and M. Ren (2017). Effects of Dietary Phosphorus Levels on Growth Performance, Plasma 
Biochemical Parameters and Relative Gene Expression of Lipogenesis of Bighead Carp, Aristichthysnobilis. Isr J Aquacult-Bamid 69.1451, 9 pages

Khajepour, F., S.A. Hosseini, and M.R. Imanpour (2012). Dietary crude protein, citric acid and microbial phytase and their interacts to influence growth performance, muscle proximate composition and hematocrit of common carp, Cyprinus carpio L, juveniles. World J Zool. 7: 118-122.

Kokou, F., G. Rigos, M. Henry, M. Kentouri, and M. Alexis (2012). Growth performance, feed utilization and non-specific immune response of gilthead sea bream (Sparus aurata L.) fed graded levels of a bioprocessed soybean meal. Aquacul. 364: 74-81.

Lanari, D., E.D. Agaro, and C. Turri (1998). Use of nonlinear regression to evaluate the effects of phytase enzyme treatment of plant protein diets for rainbow trout (Oncorhynchus mykiss). Aquacul. 161: 345-356.

Lei, X. G., J.D. Weaver, E. Mullaney, A.H. Ullah, and M.J. Azain (2013). Phytase, a new life 660 For an "old" enzyme, Annu. Rev. Anim. Biosci. 1: 283-309.

Liang, L. W. Cong, L. Shaoguang, C. Xuemei, and S. Kunlai. (2019) Nutritional compositions of Indian Moringa oleifera seed and antioxidant activity of its polypeptides. Food Sci Nutr. 2019;7:1754-1760.

Liu, L.W., J.M. Su, T. Zhang, X.Z. Liang, and Y.L. Luo (2013). Apparent digestibility of nutrients in grass carp diet supplemented with graded levels of phytase using pre-treatment and spraying methods. Aqua Nutr. 19: 91-99.

Lovell, R.T. (1989). Van Nostrand-Reinhold, New York. Nutrition and feeding of fish. 260.

Mahmoud, M.A., M. Abdelsalam, O.A. Mahdy, H.M.F. El-Minawi, Z.A.M. Ahmed, A.H. Osman, H.M.H. Mohamed, M.A. Khattab, and M.A.Z. Ewiss (2016). Infectious bacterial pathogens, parasites and pathological correlations of sewage pollution as an important threat to farmed fishes in Egypt. Environ Pollut. 219: 939-948.

National Research Council (NRC) (1993). Washington, DC, National Academy Press. Nutrient Requirements of Fish. 114.

Norag, M.A. A., A.M. El-Shenawy, S.E. Fadl, W.S. Abdo, D.M. Gad, M.A. Rashed, and A.M. Prince (2018). Effect of phytase enzyme on growth performance, serum biochemical alteration, immune response and gene expression in Nile tilapia. Fish Shellfish. Immunol.80: 97-108.
Nwanna, L.C., C.A. Oishi, and M.P. Filho (2008). Use of phytase to improve the digestibility of alternative feed ingredients by Amazon tambaqui, Colossoma macropomum. J Sci Asia. 34:353-360.

Olusola S.E., andL.C. Nwanna (2014). Growth performance of Nile Tilapia (Oreochromis niloticus) fed processed soybean meal based diets added with phytase. Int J Aquacul. 8: 48-54

Roberts, R. J. (1978). In:R. J. Roberts, editor. Fish pathology. Bailliere Tindal, London, UK. The pathophysiology and systemic pathology of teleosts. 55-91

Robinson, E. H., M. H. Li, andB. B. Manning (2002). Comparison of microbial phytase and dicalcium phosphate or growth and bone mineralization of pond raised channel catfish, Ictalurus punctatus. J Appl Aquacul. 12: 81-88.

Rowland, S.J., and B.A. Ingram (1991). In: Fisheries Bulletin 4 NSW Fisheries, Sydney, NSW, Australia. Diseases of Australian native fishes.

Sardar, P., H.S. Randhawa, M. Abid, and S.K. Prabhakar (2007). Effect of dietary microbial phytase addition on growth performance, nutrient utilization, body compositions and haematobiochemical profiles of Cyprinus carpio (L.) fingerlings fed soyprotein-based diet. Aquacul Nutrit. 13:444-456.

Schalm,J.N.C. (1986) Veterinary Haematology, 4th edn.(Lea and Febiger, USA).

Selle, P.H., V. Ravindran, A. Caldwell, and W.L. Bryden (2000). Phytate and phytase: consequences for protein utilization. Nutr Res Reviews. 13: 255 278.

Shahzad, M. M., S.M. Hussain, A.M. Akram, A. Javid, M. Hussain, S.Z.H. Shah, and A. Chaudhary (2019). Improvement in nutrient digestibility and growth performance of Catla catla fingerlings using phytase in Moringa oleifera leaf meal based diet. Pak J Zool. 1(51): 157-168.

Shahzad, M. M., S.M. Hussain, M. Hussain, M. Tariq, N. Ahmed, M. Furqan, F. Khalid and T. Rafique (2020). Improvement in Overall Performance of Catla catla Fingerlings Fed Phytase included Low Cost Plant by Products-Based Diet. Saudi J Biol Sci. 27: 2089-2096.

Shahzad, M.M., S.M. Hussain, F. Jabeen, A.I. Hussain, A. Javid, M. Asrar, and M.Z.H. Arslan (2018). Improvement in mineral digestibility and whole body composition of Catla catla fingerlings fed phytase added MOSM based diet. Pak J Zool. 50: 1909-1920.

Shahzad, M.M., S.M. Hussain, F. Jabeen, A.I. Hussain, M.Z.H. Arslan, N. Ahmad, M.M.H. Rehan, andD. Riaz (2016). Carcass composition and hematological study of Catla catla fingerlings 
fed on phytase added Moringa oleifera leaf meal (MOLM) based diet. J Biodive Environ Sci (JBES). 1: 57-68.

Sitjà-Bobadilla, A., S. Peña-Llopis, P. Gómez-Requeni, F. Médale, S. Kaushik, andJ. Pérez-Sánchez (2005). Effect of fish meal replacement by plant protein sources on non-specific defence mechanisms and oxidative stress in gilthead sea bream (Sparus aurata). Aquacul. 249: 387-400.

Snedecor, G. W, and W. G. Cochran (1991). Statistical Methods. $8^{\text {th }}$ Ed. Iowa State University. Press, Ames. USA, p. 503.

Soivio, A, and A. Oikari (1976). Hematological effects of stress on a teleost, Esoxlucius L J fish Bio. 8: 397-411.

Soliva, C.R., M. Kreuzer, N. Foidl, G. Foidl, A.Machmüller, and H.D. Hess (2005). Feeding value of whole and extracted Moringa oleifera leaves for ruminants and their effects on ruminal fermentation in vitro. Anim Feed Sci Technol. 118: 47-62.

Sugiura, S.H., J. Gabaudan, F.M. Dong, and R.W. Hardy (2001). Dietary microbial phytase supplementation and the utilization of phosphorus, trace minerals and protein by rainbow trout [Oncorhynchus mykiss (Walbaum)] fed soybean meal-based diets. Aqua Res. 32:, 583-592.

Vohra, A., S.K. Rastogi, and T. Satyanarayana (2006). Amelioration in growth and phosphate assimilation of poultry birds using cell-bound phytase of Pichia anomala. World J Microbiol Biotechnol. 22: 553-558.

Wedemeyer, G.A., and W.T. Yastuke (1977). Clinical methods for the assessment of the effects of environ-mental stress on fish health. United States Fish and Wildlife Service Technical papers., 89.

Yildirim, O., U. Acar, Turker, M.C. Sunar andO.S. Kesbic (2014). Effects of replacing fish meal with peanut meal (Arachis hypogaea) on growth, feed utilization and body composition of Mozambique Tilapia fries (Oreochromis mossambicus). Pakistan J Zool.46: 497-502.

Yoo, G., and S.C. Bai (2014). Effects of the dietary microbial phytase addition on bioavailability of phosphorus in Juvenile Olive Flounder Paralichthy solivaceus fed soybean meal based diets. Fish Aquacul Sci. 17: 319-324. 